\title{
Three Dimensional Morphometry of Proximal Femur to Design Best-Fit Femoral Stem for Indonesian Population
}

\author{
Morfometría Tridimensional del Fémur Proximal para Diseñar \\ Prótesis a Medida en la Población de Indonesa \\ Punto Dewo*; Suyitno**; Rini Dharmastiti**; Urip A. Salim**; Luthfi Hidayat* \\ Prahesta A. Wibowo*; Zikrina A. Lanodiyu* \& Rahadyan Magetsari*
}

DEWO, P.; SUYITNO; DHARMASTITI, R.; SALIM, U.A.; HIDAYAT, L.; WIBOWO, P. A.; LANODIYU, Z.A. \& MAGETSARI. R. Three dimensional morphometry of proximal femur to design Best-Fit femoral stem for Indonesian population. Int. J. Morphol., 34(2):436-442, 2016.

SUMMARY: To design custom-made prosthesis in a certain population, the morphometry needs to be measured. The results of this study were expected to provide basic data to design the ideal size of the total hip arthoplasty prosthesis for Indonesian population. This was an anthropometric study conducted on sex matched 100 healthy Indonesian mongoloid race subjects based on Computer Tomographic (CT) imaging on the proximal femur. The parameters being used in this study were Femoral Head Offset (FHO), Femoral Head Position (FHP), Femoral Head Diameter (FHD), Neck-Shaft Angle (NSA), Anteroposterior Width (APW) and Mediolateral Width at 3 different locations, and Canal Flare Index (CFI). This study showed that Indonesian has smaller proximal femur morphometry as compared to Western population. The mean value of all parameters in male were larger than female. Moreover, FHO and FHP showed significant difference among male and female indicating the location of male femoral head center lies superiorly as compared to female. The dimension of femoral canal was found to be mediolaterally oval, 1.43, 1.28, and 1,34, respectively, in 3 different cutting ( 20 mm above and $40 \mathrm{~mm}$ below lesser trochanter, and isthmus). CFI of Indonesian was classified to be stovepipe femoral canal (2.99) that is the suggestion to use cemented femoral stem. This study showed that Indonesian proximal femur dimension has smaller build compared with Western counterpart. The proposed dimensions can be used as the basic data to design the ideal size of the femoral stem for Indonesian population.

KEY WORDS: Proximal femur morphometry; Computed tomography; Femoral stem; Indonesian population.

\section{INTRODUCTION}

In order to achieve maximal outcome of Total Hip Replacement (THR) procedures, well suited implant based on the proximal femur morphology in certain population should be made. Mismatched prosthesis or inappropriate placement of the prosthesis can lead to loosening of the prosthesis and unbalance weight distribution, and it will affect the functional outcome post operatively (McGrory $e t$ al., 1995). Bony growth into the prosthesis would be optimal when proper fit prosthesis is used which will result in long term fixation and stability (Casper et al., 2012). Undersizing stem disturbs the osteointegration process and oversizing stem lead to periprosthetic fracture due to sliding down of the stem that is too large inside the bone (Søballe et al., 1992; Berry, 2000). Micromotion can also happen at the bone-stem interface in the early days after stem implantation which can disturb trabeculae bone ingrowth. Aseptic loosening, osteolysis, and thigh pain might eventually occur due to this micromotion (Reddy et al., 1999). Improper load distribution that is transferred along the bone and stem due to differences in geometric measurements cannot prevent stress shielding. In contrast, well matched prosthesis to the internal femoral shape transfer $70-90 \%$ forces, where distal prosthesis that support stress at the metaphysis give benefit to diaphysis (Jasty et al., 1998). Therefore, the measurement of proximal femur morphometry in a certain population is strongly needed.

Differences in genetics, lifestyle, applied force and their distribution affect the build and stature size between ethnicity as shown in several studies (Hoaglund \& Low,

\footnotetext{
" Department of Orthopaedics and Traumatology Sardjito General Hospital / Faculty of Medicine, Universitas Gadjah Mada, Yogyakarta, Indonesia. **Department of Mechanical and Industrial Engineering, Faculty of Engineering, Universitas Gadjah Mada, Yogyakarta, Indonesia.
} 
1980; Igbigbi \& Msamati, 2002; Baharuddin et al., 2011). Based on some studies, it showed that the eastern population has relatively smaller measurement compared with Western population. However, currently most of the prosthesis used in Indonesia were designed based on the measurements of Western population. In addition, awareness of sex specific implants is increasing due to the differences. Nelson \& Magyesi (2004) studied the difference between male and female bone architecture and showed that male has larger build and stature compared with female.

This study was an anthropometric analysis on proximal femur obtained from normal Indonesian hip using three dimensional computer tomographic measurements. The results of the measurement were expected to provide basic data to design the ideal size of total hip arthoplasty prosthesis for South East Asian population in general and for Indonesian population specifically.

\section{MATERIAL AND METHOD}

Subjects. This was a descriptive analytic study conducted on sex matched 100 healthy Indonesian mongoloid race subjects with Javanese ethnicity. The subjects were 20 to 70 years old. The inclusion criteria of this study were subjects with normal alignment of the lower extremity, absence of neuromuscular deformity and abnormality, absence of signs and symptoms of the hip arthritis, and independent daily activities performed by the subjects. The researchers selected the subjects by random sampling from the population of Indonesian mongoloid race lived in Yogyakarta, Indonesia. Information regarding this study was well delivered to those eligible subjects and consent was taken. This study was approved by ethical committees from Faculty of Medicine Universitas Gadjah Mada. Measurement of the proximal hip morphometry parameters was using right hip of the subjects.

Computer tomographic (CT) technique. The proximal hip morphology in this study was measured based on Computer Tomographic (CT) imaging using CT-Scan Phillips ingenuity core 128,128 slices $120 \mathrm{kvp}, 2.0 \mathrm{~mm}$. The subjects were asked to lie in supine position with the lower extremity in anatomical position. The retrieved image was formed in the file shape of DICOM 3.0, it was then reconstructed into 3D image with Phillips Intelli space portal CT viewer version 4.0.0.1921 software that was integrated with the CT Scan. The proximal femur 3D model image was 360 degree rotatable, could be cut and measured into desired area.

Proximal femoral cuts and morphometry measurements. The parameters of proximal femur being used in this study were Femoral Head Offset (FHO), Femoral Head Position (FHP), Femoral Head Diameter (FHD), Neck Shaft Angle (NSA), Anteroposterior width at section 1 (APW1), Mediolateral width at section 1 (MLW1), Anteroposterior width at section 2 (APW2), Mediolateral width at section 2 (MLW2), Anteroposterior width at section 3 (APW3), and Mediolateral width at section 3 (MLW3). FHO was measured as the line drawn from femoral head center to the femoral shaft axis, and the measurement of femoral head center position based on the lesser trochanter was called FHP. FHD was the maximum diameter of the femoral head. FNSA was the angle that was formed between femoral neck axis and femoral shaft axis. For APW and MLW, the proximal femur was cut at 3 levels perpendicular to femoral anatomical axis. First measurement or APW1 and MLW1 were measured 20 $\mathrm{mm}$ above lesser trochanter, second measurement or APW2 and MLW2 were measured $40 \mathrm{~mm}$ below lesser trochanter, and the third measurement or APW3 and MLW3 were measured at isthmus section. APW was portrayed as the proximal femur anteroposterior dimension and drawn as the longest anteroposterior length of the proximal femur cut surface, meanwhile the MLW portrayed the mediolateral aspect of the cut surface and it was drawn as the perpendicular line that passed through the midpoint of APW line in each cut surface.

Independent $\mathrm{T}$ test was used to analyze the proximal femur morphology between male compared with female subjects and Pearson correlation test was used to determine the correlation between variables. Proposed dimension of the proximal femur components was calculated based on 25,50 , and 75 percentile of the data. Values for $p<0.05$ was regarded as statistically significant.

\section{RESULTS}

We studied the morphology of proximal femur of 100 normal knee with equal number of male and female. The mean of age was 49.9 years and it was not significantly different between male and female subjects with $\mathrm{p}$ value 0.767. All the subjects in this study did not have severe changes in the hip. Table I showed the mean of all parameters measured in this study. The comparison of parameter measurement result in this study and other studies conducted in several countries was shown in Table II.

This study showed that there were significant differences between male and female in 6 out of 10 parameters measured. There were FHO, FHP, FHD, APW1, MLW1, and APW2. However, the CFI showed similar proportion between male and female (Table III). AP and ML 
Table I. Morphology of proximal femur in all sex subjects.

\begin{tabular}{lcccccc}
\hline & $\boldsymbol{n}$ & Min. & Max. & Median & Mean \pm SD & $\begin{array}{c}\text { 95\% CI for mean } \\
\text { (lower }- \text { upper) }\end{array}$ \\
\hline Age & 100 & 20 & 73 & 55 & $49.95 \pm 15.71$ & $46.83-53.07$ \\
FHO & 100 & 22.90 & 52.30 & 35.40 & $35.18 \pm 5.24$ & $34.13-36.22$ \\
FHP & 100 & 39.10 & 73.90 & 53.65 & $53.77 \pm 7.70$ & $52.24-55.30$ \\
FHD & 100 & 38.30 & 53.50 & 45.70 & $45.35 \pm 3.82$ & $44.59-46.11$ \\
NSA & 100 & 110.00 & 139.00 & 128.00 & $127.91 \pm 4.96$ & $126.92-128.89$ \\
APW $_{1}$ & 100 & 21.40 & 42.00 & 29.95 & $30.14 \pm 3.58$ & $29.43-30.85$ \\
MLW $_{1}$ & 100 & 32.60 & 72.70 & 42.60 & $43.09 \pm 5.47$ & $42.01-44.18$ \\
APW $_{2}$ & 100 & 7.90 & 19.10 & 12.60 & $12.83 \pm 2.28$ & $12.38-13.29$ \\
MLW $_{2}$ & 100 & 10.80 & 23.00 & 16.20 & $16.40 \pm 2.69$ & $15.87-16.94$ \\
APW $_{3}$ & 100 & 7.50 & 18.00 & 11.05 & $11.10 \pm 1.91$ & $10.72-11.48$ \\
MLW $_{3}$ & 100 & 10.30 & 23.10 & 14.60 & $14.79 \pm 2.71$ & $14.25-15.33$ \\
CFI & 100 & 1.70 & 5.3 & 2.95 & $2.99 \pm 0.60$ & $2.87-3.11$ \\
\hline
\end{tabular}

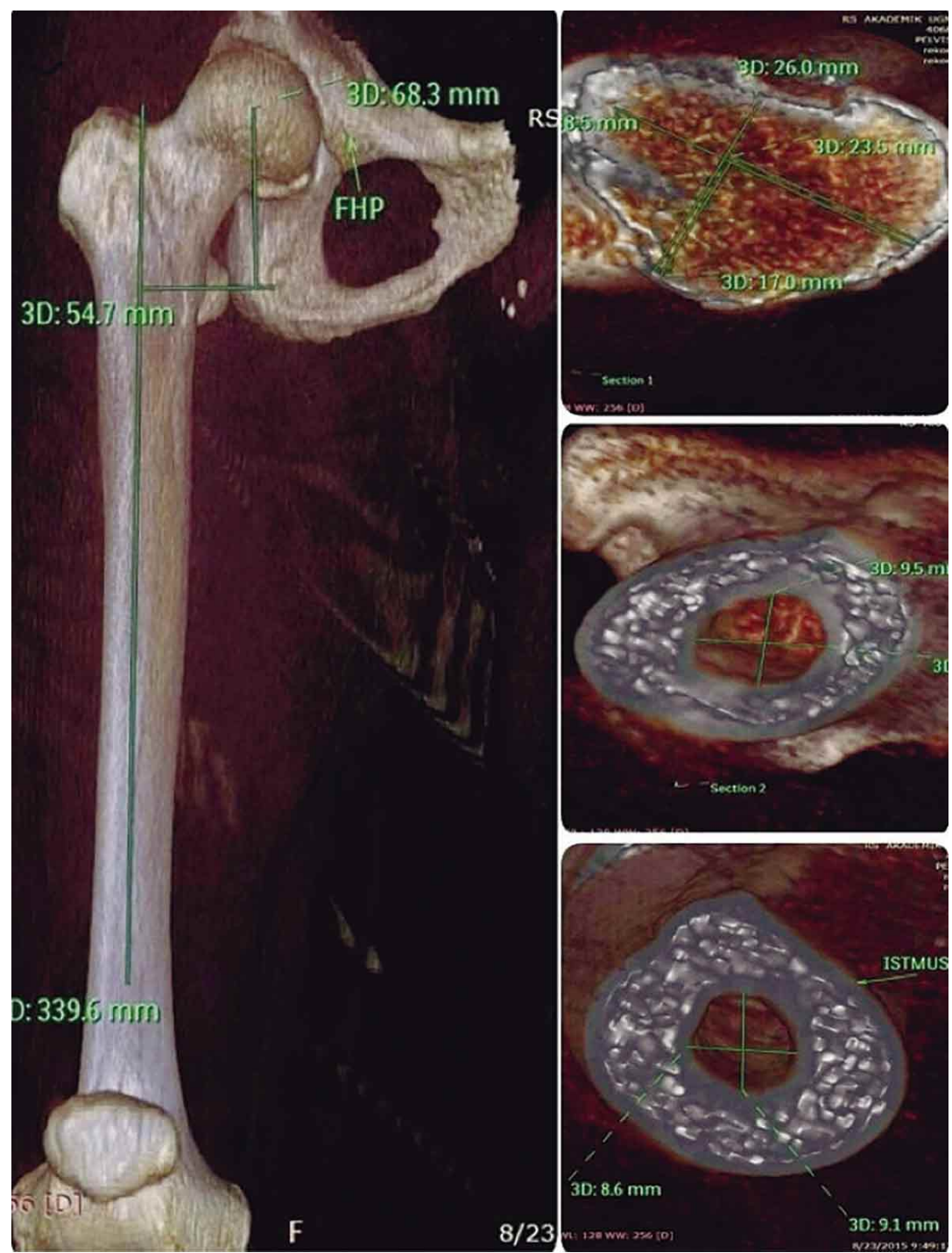

Fig. 1. Three dimensional CT image of the proximal femur showing the parameters used in this study. were measured in 3 different locations. The morphological relationship between femoral head position from lesser trochanter and femoral head offset was shown in Figure 2. Figure 3 showed the variation of mean ML and AP canal width where it revealed that the AP and ML at $20 \mathrm{~mm}$ above lesser trochanter was larger compared at isthmus and $40 \mathrm{~mm}$ below lesser trochanter in terms of size. Figure 4 showed aspect ratio of ML canal width per AP canal width at 3 different locations among male, female, and all subjects. The proposed dimensions of the proximal femoral components for hip prostheses were seen in Table IV. 

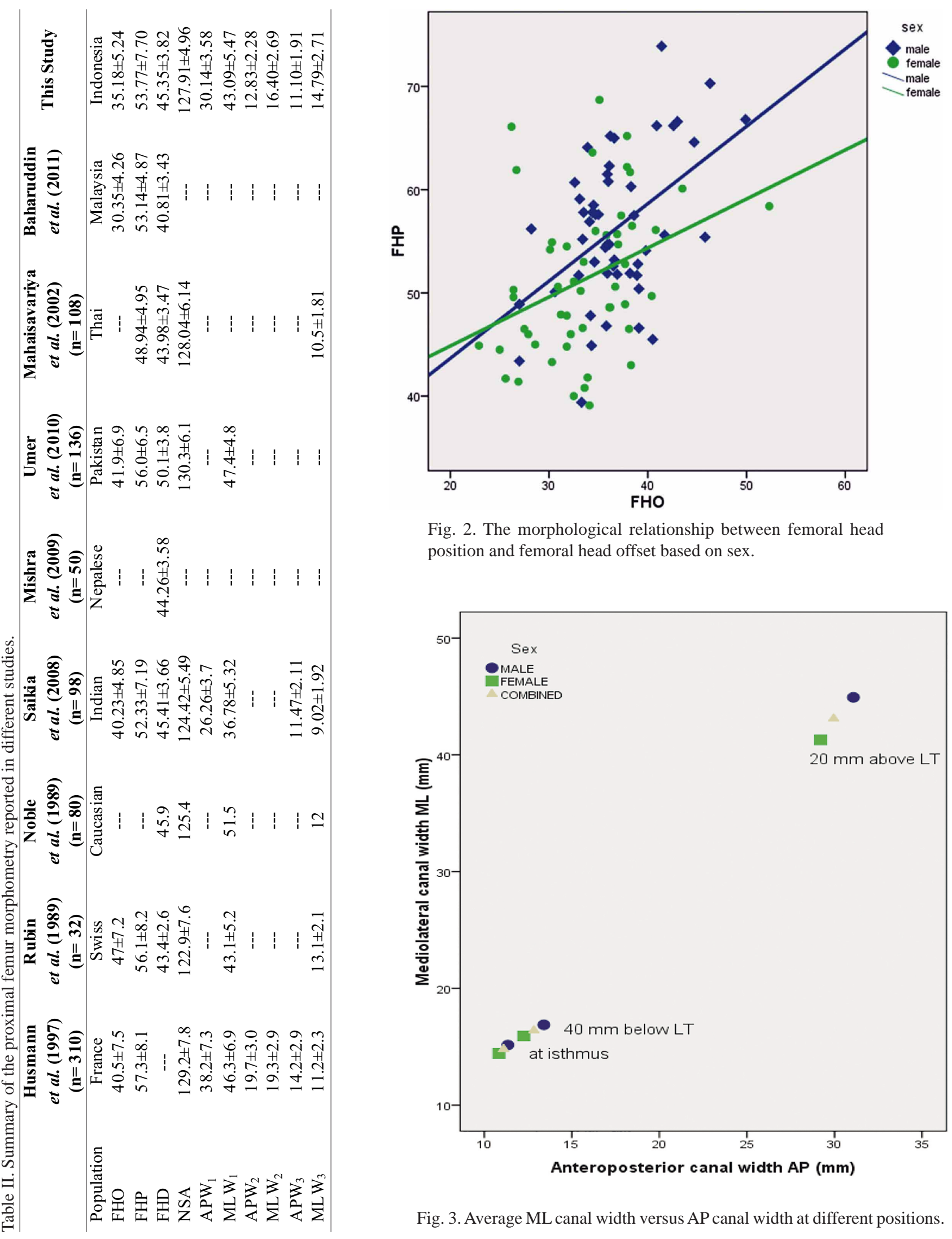

Fig. 2. The morphological relationship between femoral head position and femoral head offset based on sex.

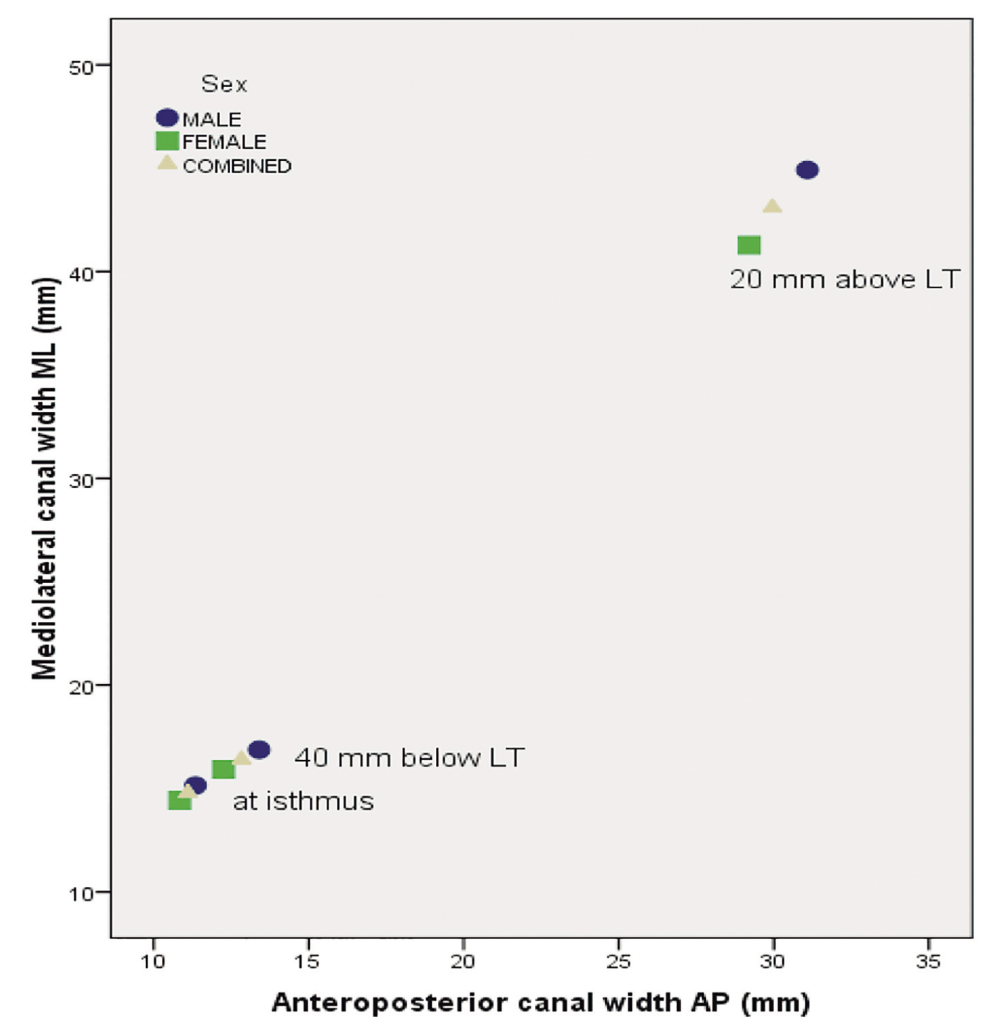

Fig. 3. Average ML canal width versus AP canal width at different positions. 
DEWO, P.; SUYITNO; DHARMASTITI, R.; SALIM, U. A.; HIDAYAT, L.; WIBOWO, P. A.; LANODIYU, Z. A. \& MAGETSARI. R. Three dimensional morphometry of proximal femur to design Best-Fit femoral stem for Indonesian population. Int. J. Morphol., 34(2):436-442, 2016.

Table III. Descriptive statistic and comparison between male and female subjects (mm).

\begin{tabular}{|c|c|c|c|c|c|c|c|}
\hline & Sex & $n$ & $\operatorname{Mean} \pm$ SD & $\begin{array}{c}\text { SE } \\
\text { Mean }\end{array}$ & $\begin{array}{c}\text { Mean } \\
\text { Difference }\end{array}$ & $\begin{array}{l}\text { 95\% CI for difference } \\
\text { (lower - upper) }\end{array}$ & $\begin{array}{c}\text { Sig. } \\
\text { (2-tailed) }\end{array}$ \\
\hline \multirow{2}{*}{ FHO } & Male & 50 & $36.78 \pm 4.59$ & 0.64942 & \multirow{2}{*}{3.21} & \multirow{2}{*}{$1.22-5.20$} & \multirow{2}{*}{0.002} \\
\hline & Female & 50 & $33.57 \pm 5.40$ & 0.76409 & & & \\
\hline \multirow{2}{*}{ FHP } & Male & 50 & $56.24 \pm 7.27$ & 1.02830 & \multirow{2}{*}{4.93} & \multirow{2}{*}{$2.02-7.84$} & \multirow{2}{*}{0.001} \\
\hline & Female & 50 & $51.30 \pm 7.39$ & 1.04523 & & & \\
\hline \multirow[t]{2}{*}{ FHD } & Male & 50 & $47.22 \pm 3.24$ & 0.45822 & \multirow[t]{2}{*}{3.73} & \multirow[t]{2}{*}{$2.39-5.06$} & \multirow[t]{2}{*}{0.000} \\
\hline & Female & 50 & $43.49 \pm 3.46$ & 0.49053 & & & \\
\hline \multirow{2}{*}{ NSA } & Male & 50 & $128.10 \pm 4.42$ & 0.62548 & \multirow{2}{*}{0.28} & \multirow{2}{*}{$-1.59-2.36$} & \multirow{2}{*}{0.704} \\
\hline & Female & 50 & $127.72 \pm 5.48$ & 0.77620 & & & \\
\hline \multirow{2}{*}{$\mathrm{APW}_{1}$} & Male & 50 & $31.08 \pm 3.36$ & 0.47578 & \multirow[t]{2}{*}{1.87} & \multirow[t]{2}{*}{$0.49-3.25$} & \multirow{2}{*}{0.008} \\
\hline & Female & 50 & $29.21 \pm 3.57$ & 0.50581 & & & \\
\hline \multirow{2}{*}{$\mathrm{MLW}_{1}$} & Male & 50 & $44.91 \pm 5.92$ & 0.83754 & \multirow[t]{2}{*}{3.63} & \multirow{2}{*}{$1.57-5.69$} & \multirow{2}{*}{0.001} \\
\hline & Female & 50 & $41.27 \pm 4.32$ & 0.61199 & & & \\
\hline \multirow{2}{*}{$\mathrm{APW}_{2}$} & Male & 50 & $13.40 \pm 2.53$ & 0.35886 & \multirow[t]{2}{*}{1.15} & \multirow{2}{*}{$0.26-2.02$} & \multirow[t]{2}{*}{0.012} \\
\hline & Female & 50 & $12.26 \pm 1.86$ & 0.26380 & & & \\
\hline \multirow{2}{*}{$\mathrm{MLW}_{2}$} & Male & 50 & $16.88 \pm 2.72$ & 0.38486 & \multirow[t]{2}{*}{0.95} & \multirow[t]{2}{*}{$-0.10-2.00$} & \multirow{2}{*}{0.077} \\
\hline & Female & 50 & $15.93 \pm 2.60$ & 0.36776 & & & \\
\hline \multirow[t]{2}{*}{$\mathrm{APW}_{3}$} & Male & 50 & $11.35 \pm 1.90$ & 0.26953 & \multirow[t]{2}{*}{0.51} & $-0.25-1.27$ & 0.183 \\
\hline & Female & 50 & $10.84 \pm 1.91$ & 0.27095 & & & \\
\hline $\mathrm{MLW}_{3}$ & Male & 50 & $15.15 \pm 2.85$ & 0.40423 & 0.72 & $-0.35-1.79$ & 0.187 \\
\hline & Female & 50 & $14.43 \pm 2.54$ & 0.36037 & & & \\
\hline CFI & Male & 50 & $3.06 \pm 0.67$ & 0.09527 & 0.132 & $-0.106-370$ & 0.275 \\
\hline & Female & 50 & $2.93 \pm 0.51$ & 0.51794 & & & \\
\hline
\end{tabular}

Table IV. Proposed dimension of the proximal femur components in hip prostheses.

\begin{tabular}{|c|c|c|c|c|c|c|c|c|c|c|c|c|c|c|c|}
\hline & & 0 & HP & FHD & SA & 1 & $N$ & A PW, & MLW, & $\mathbf{A P W}_{3}$ & MLW, & CFI & $\begin{array}{c}\text { Mlper } \\
\text { AP1 }_{1}\end{array}$ & $\begin{array}{c}\text { Mlper } \\
\mathbf{A P}_{2}\end{array}$ & $\begin{array}{r}\text { Mlper } \\
\text { AP }_{3} \\
\end{array}$ \\
\hline & & 0 & 100 & 100 & 1 & 100 & 100 & 100 & 100 & 10 & 10 & 0 & 100 & & 100 \\
\hline \multirow[t]{3}{*}{ Percentile } & 25 & & & & & & & & & & & & & & 24 \\
\hline & 50 & & & & & & & & & & & 2.93 & 1.? & 1.2 & 1.33 \\
\hline & 75 & 38.17 & 58.47 & 47.97 & 131.00 & 32.57 & 46.32 & 13.90 & 18.62 & 12.27 & 16.17 & 3.40 & 1.50 & 1.38 & 1.40 \\
\hline
\end{tabular}

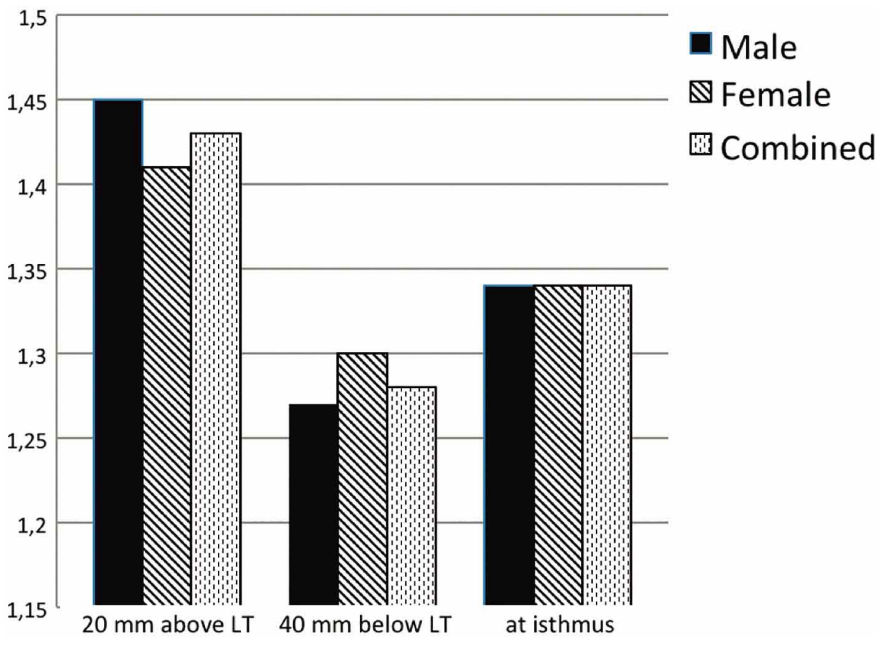

Fig. 4. Comparison of aspect ratio (MLW/APW) in 3 different positions of proximal femur. 


\section{DISCUSSION}

Well-suited implant will lead to better outcome, therefore, it is necessary to design custom made prosthesis based on certain population morphometry. Several studies showed that Asian population have a smaller build and stature compared with Western population. We tried to compare the results of our study with other studies conducted in several countries either using CT Scan or X-ray based measurement on proximal femur. Our study showed that Indonesian population has smaller femoral head dimension compared with Western population (Noble et al., 1988; Rubin et al., 1989; Hussmann et al., 1997). However, among southeast Asian, such as Thai and Malaysian, our study showed that Indonesia has larger femoral head morphometry (Baharuddin et al.; Mahaisavariya et al., 2002). Extramedullary dimensions (femoral head position, femoral head offset, and ante version angle) play an important role in maintaining proper hip kinematics and it will affect the satisfaction of post-operative result (Sugano et al., 1999; Ranawat \& Rodriguez, 1997).

The difference in hip shape and load distribution between male and female might affect the differences in the morphometry measurement as shown in this study where male showed larger measurement compared with female (Rawal et al., 2012). Moreover, earlier research conducted by an anthropologists in $17^{\text {th }}$ centuries showed that there were differences in the head femur measurement between sexes (Gomez \& Morcuende, 2005). Among sex, this study reflected the morphological relationship between FHP and FHO in Figure 2 and it showed that FHO and FHP only have moderate relationship based on Pearson correlation statistics. Compared to another study conducted by Baharuddin et al., similar results were shown. They showed that FHO and FHP did not have correlation.

The size of femoral canal dimension should be taken into account to provide primary stability during the design evolution stage (Rawal et al.). A big gap was seen in Figure 3 between measurement result at $20 \mathrm{~mm}$ above lesser trochanter and $40 \mathrm{~mm}$ below lesser trochanter. It showed that Indonesian has quite larger femoral canal size at $20 \mathrm{~mm}$ above lesser trochanter compared with the measurement in the isthmus and $40 \mathrm{~mm}$ below lesser trochanter. To predict the shape of the anticipated femoral stem, this study measured the aspect ratio of proximal femur at 3 different locations. ML per AP canal width can predict the shape of proximal femur transversely. Figure 4 indicates that the shape of proximal femur aspect ratio was mediolaterally oval, the most mediolaterally oval was seen in $20 \mathrm{~mm}$ above lesser trochanter, and it was relatively similar between male and female.
CFI is one of important parameters to design wellmatched prosthesis because it defines frontal plane proximal femur morphology. This study showed that mean CFI for Indonesian population was 2.99. Because it was lower than 3, Indonesian have stovepipe femoral canal (3-5 is normal; $>5$ is champagne-fluted). Based on Fessy et al. (1997) stovepipe femoral canal suggest the use of cemented femoral stem in hip arthoplasty procedure. However, this study did not compare the CFI in terms of age, even though CFI decreased with age due to cortical bone loss. Decrease in the cortice will eventually cause isthmus width increase and lead to overall flare decrease (Casper et al.).

This study was expected to be the basic data for further study in designing femoral stem implant for Indonesian population. In order to achieve well-matched femoral stem and good functional outcome post operatively. Further study based on wider variety of sample selection of Indonesian mongoloid races is needed and this study can guide the development of total hip prosthesis for Indonesian population.

\section{CONCLUSION}

The anthropometric data on proximal hip morphometry of Indonesian population showed that Indonesian people have smaller build compared with Western counterpart. This study may provide guidance for designing well matched hip prosthesis for Indonesian population based on the dimension proposed in this study.

\section{ACKNOWLEDGEMENTS}

We acknowledge the financial support of the Pusnas DIKTI. We thanked Gadjah Mada Hospital for allowing us to use the CT workstation.

DEWO, P.; SUYITNO; DHARMASTITI, R.; SALIM, U. A.; HIDAYAT, L.; WIBOWO, P. A.; LANODIYU, Z. A. \& MAGETSARI. R. Morfometría tridimensional del fémur proximal para diseñar prótesis a medida en la población de Indonesa. Int. J. Morphol., 34(2):436-442, 2016.

RESUMEN: Para diseñar prótesis a medida en una población determinada, la morfometría necesita ser conocida. El objetivo de este estudio fue obtener resultados que sean útiles en la investigación para diseñar el tamaño ideal de una prótesis total de artroplastía de cadera para la población de Indonesia. Fue realizado un estudio antropométrico en 100 sujetos sanos de raza mongoloide de Indonesia, en los que se estudió la parte proximal del fémur por tomografía computadorizada 
(TC). Se consideraron como parámetros la cabeza del fémur (CF), posición de la cabeza del fémur (PCF), diámetro de la cabeza del fémur (DCF), ángulo cérvicodiafisario (ACD), ancho anteroposterior (AAP) y ancho-lateral en 3 lugares diferentes. La población Indonesia tiene una morfometría menor del fémur proximal en comparación con la población occidental. El valor medio de todos los parámetros en hombres fueron mayores a las mujeres. Por otra parte, CF y PCF mostraron diferencia significativa entre hombres y mujeres e indicó una ubicación superior del centro de la cabeza del fémur en hombres, en comparación con las mujeres. Se encontró que la dimensión del canal femoral fue mediolateral oval, 1,43, 1,28, y 1,34, en 3 cortes diferentes, respectivamente $(20 \mathrm{~mm}$ superior y $40 \mathrm{~mm}$ inferior del trocánter menor e istmo). La dimensión del fémur proximal en la población de Indonesia es de menor tamaño en comparación con la contraparte occidental. Las dimensiones propuestas se pueden utilizar como datos básicos para el diseño de un tamaño ideal de vástago femoral para la población Indonesia.

PALABRAS CLAVE: Morfometría de femur proximal; Tomografía computadorizada; Vástago femoral; Población Indonesia.

\section{REFERENCES}

Baharuddin, M. Y.; Kadir, M. R. A.; Zulkifly, A. H.; Saat. A.; Aziz, A. A. \& Lee, M. H. Morphology study of the proximal femur in malay population. Int. J. Morphol., 29(4):1321-5, 2011.

Berry, D. J. Management of periprosthetic fractures: the hip. J. Arthroplasty, 17(4 Suppl. 1):11-3, 2000.

Casper, D. S.; Kim, G. K.; Parvizi, J. \& Freeman, T. A. Morphology of the proximal femur differs widely with age and sex: relevance to design and selection of femoral prostheses. J. Orthop. Res., 30(7):1162-6, 2012.

Fessy, M. H.; Seutin, B. \& Béjui, J. Anatomical basis for the choice of the femoral implant in the total hip arthroplasty. Surg. Radiol. Anat., 19(5):283-6, 1997.

Gomez, P. F. \& Morcuende, J. A. Early attempts at hip arthroplasty--1700s to 1950s. Iowa Orthop. J., 25:25-9, 2005.

Hoaglund, F. T. \& Low, W. D. Anatomy of the femoral neck and head, with comparative data from Caucasians and Hong Kong Chinese. Clin. Orthop. Relat. Res., (152):10-6, 1980.

Hussmann, O.; Rubin, P. J.; Leyvraz, P. F.; de Roguin, B. \& Argenson, J. N. Three-dimensional morphology of the proximal femur. J. Arthroplasty, 12(4):444-50, 1997.

Igbigbi, P. S. \& Msamati, B. C. The femoral collodiaphyseal angle in Malawian adults. Am. J. Orthop. (Belle Mead N. J.), 31(12):682-5, 2002.

Jasty, M.; Henshaw, P. M. \& O'Connor, D. O. Strain Alterations in the Proximal Femur with an Uncemented Femoral Prosthesis Emphasizing the Effect of Component Fix. Atlanta, Proc. Orthopaedic Research Society Meeting, 1988. pp.335.
Mahaisavariya, B.; Sitthiseripratip, K.; Tongdee, T.; Bohez, E. L.; Vander Sloten, J. \& Oris, P. Morphological study of the proximal femur: a new method of geometrical assessment using 3-dimensional reverse engineering. Med. Eng. Phys., 24(9):617-22, 2002.

McGrory, B. J.; Morrey, B. F,; Cahalan, T. D.; An, K. N. \& Cabanela, M. E. Effect of femoral offset on range of motion and abductor muscle strength after total hip arthroplasty. J. Bone Joint Surg., 77(6):865-9, 1995.

Mishra, A. K.; Chalise, P.; Singh, R. P. \& Shah, R. K. The proximal femur-a second look at rational of implant design. Nepal Med. Coll. J., 11(4):278-80, 2009,

Nelson, D. A. \& Megyesi, M. S. Sex and ethnic differences in bone architecture. Curr. Osteoporos. Rep., 2(2):65-9, 2004.

Noble, P. C.; Alexander, J. W.; Lindhal, L. J.; Yew, D. T.; Granberry, W. M. \& Tullos, H. S. The anatomic basis of femoral component design. Clin. Orthop. Relat. Res., (235):148-65, 1988.

Ranawat, C. S. \& Rodriguez, J. A. Functional leg-length inequality following total hip arthroplasty. J. Arthoplasty, 12(4):359-64, 1997.

Rawal, B.; Ribeiro, R.; Malhotra, R. \& Bhatnagar, N. Anthropometric measurements to design best-fit femoral stem for the Indian population. Indian J. Orthop., 46(1):46-53, 2012.

Reddy, V. S.; Moorthy, G. V. S. \& Reddy, S. G. Do we need a spe-cial design of femoral component of total hip prosthesis in our patients? Ind. J. Orthop., 33(4):282-4, 1999.

Rubin, P. J.; Leyvraz, P. F. \& Heegaard, J. H. Radiologic changes of anatomic parameters of the proximal femur as a function of its position in rotation. Rev. Chir. Orthop. Reparatrice Appar. Mot., 75(4):209-15, 1989.

Saikia, K. C.; Bhuyan, S. K. \& Rongphar, R. Anthropometric study of the hip joint in northeastern region population with computed tomography scan. Indian J. Orthop., 42(3):260-6, 2008.

Søballe, K.; Hansen, E. S.; B-Rasmussen, H.; Jørgensen, P. H. \& Bünger, C. Tissue ingrowth into titanium and hydroxyapatite-coated implants during stable and unstable mechanical conditions. J. Orthop. Res., 10(2):285-99, 1992.

Sugano, N.; Noble, P. C. \& Kamaric, E. Predicting the position of the femoral head center. J. Arthoplasty, 14(1):102-7, 1999.

Umer, M.; Sepah, Y. J.; Khan, A.; Wazir, A.; Ahmed, M. \& Jawad, M. U. Morphology of the proximal femur in a Pakistani population. J. Orthop. Surg. (Hong Kong), 18(3):279-81, 2010.

\section{Corresponddence to: \\ Punto Dewo, MD., PhD. Mada Jalan Kesehatan no. 1, Sekip \\ Yogyakarta 55284 \\ INDONESIA}

Department of Orthopaedics and Traumatology, Sardjito General Hospital / Faculty of Medicine Universitas Gadjah

Email: dewo777@yahoo.com 